\title{
Identification of markers associated with bacterial blight resistance loci in cowpea [Vigna unguiculata (L.) Walp.]
}

\author{
E. M. Agbicodo $\cdot$ C. A. Fatokun $\cdot$ R. Bandyopadhyay $\cdot$ K. Wydra $\cdot$ \\ N. N. Diop - W. Muchero - J. D. Ehlers $\cdot$ P. A. Roberts $\cdot$ T. J. Close $・$ \\ R. G. F. Visser $\cdot$ C. G. van der Linden
}

Received: 16 October 2009/ Accepted: 22 March 2010/Published online: 18 April 2010

(C) The Author(s) 2010. This article is published with open access at Springerlink.com

\begin{abstract}
Cowpea bacterial blight (CoBB), caused by Xanthomonas axonopodis pv. vignicola $(\mathrm{Xav})$, is a worldwide major disease of cowpea [Vigna unguiculata (L.) Walp.]. Among different strategies to control the disease including cultural practices, intercropping, application of chemicals, and sowing pathogen-free seeds, planting of cowpea genotypes with resistance to the pathogen would be the most attractive option to the resource poor cowpea farmers in sub-Saharan Africa. Breeding resistance cultivars would be facilitated by marker-assisted selection (MAS). In order to identify loci with effects on
\end{abstract}

E. M. Agbicodo $(\bowtie) \cdot$ C. A. Fatokun ·

R. Bandyopadhyay

International Institute of Tropical Agriculture (IITA),

PMB 5320, Oyo Road, Ibadan, Nigeria

e-mail: eugene.agbicodo@wur.nl

E. M. Agbicodo - R. G. F. Visser - C. G. van der Linden Wageningen UR Plant Breeding, Wageningen University and Research Centre, Droevendaalsesteeg 1,

6708 PB Wageningen, The Netherlands

K. Wydra

Centre for Tropical and Subtropical Agriculture and

Forestry (CeTSAF), Tropenzentrum Georg-August

Universität Goettingen Buesgenweg 1, 37077

Goettingen, Germany

N. N. Diop · W. Muchero · J. D. Ehlers ·

P. A. Roberts - T. J. Close

Department of Botany and Plant Sciences, University

of California, Riverside, CA 92521-0124, USA resistance to this pathogen and map QTLs controlling resistance to $\mathrm{CoBB}$, eleven cowpea genotypes were screened for resistance to bacterial blight using 2 virulent Xav18 and Xav19 strains isolated from Kano (Nigeria). Two cowpea genotypes Danila and Tvu7778 were identified to contrast in their responses to foliar disease expression following leaf infection with pathogen. A set of recombinant inbred lines (RILs) comprising 113 individuals derived from Danila (resistant parent) and Tvu7778 (susceptible parent) were infected with CoBB using leaf inoculation method. The experiments were conducted under greenhouse conditions (2007 and 2008) and disease severity was visually assessed using a scale where $0=$ no disease and $4=$ maximum susceptibility with leaf drop. A single nucleotide polymorphism (SNP) genetic map with 282 SNP markers constructed from the same RIL population was used to perform QTL analysis. Using Kruskall-Wallis and Multiple-QTL model of MapQTL 5, three QTLs, CoBB-1, CoBB-2 and CoBB-3 were identified on linkage group LG3, LG5 and LG9 respectively showing that potential resistance candidate genes cosegregated with $\mathrm{CoBB}$ resistance phenotypes. Two of the QTLs CoBB-1, CoBB-2 were consistently confirmed in the two experiments accounting for up to 22.1 and to $17.4 \%$ respectively for the first and second experiments. Whereas CoBB-3 was only discovered for the first experiment (2007) with less phenotypic variation explained of about $10 \%$. Our results represent a resource for molecular marker 
development that can be used for marker assisted selection of bacterial blight resistance in cowpea.

Keywords Cowpea - Bacterial blight .

Source of resistance $\cdot$ SNP - QTL mapping

\section{Introduction}

Cowpea [Vigna unguiculata (L.) Walp., Fabaceae $(2 n=2 \times=22)]$ is an essential leguminous crop in less-developed countries of the tropics and subtropics, especially in sub-Saharan Africa, Asia and Latin America (Singh et al. 1997). Besides fungal and viral diseases, bacterial blight and pustules caused by Xanthomonas axonopodis pv. vignicola (Xav) (Vauterin et al. 1995), formerly X. campestris pv. vignicola (Burkholder 1944) is the most important disease of cowpea. CoBB is prevalent in all major cowpea growing areas of the world (Gitaitis 1983; Emechebe and Florini 1997), causing severe grain yield loss of more than $64 \%$ in some areas of West Africa (Sikirou 1999). When highly susceptible cultivars are sown the crop may even be completely destroyed (Emechebe and Shoyinka 1985). The symptoms of CoBB appear as tiny, water-soaked, translucent spots, which are more clearly visible from the abaxial surface of the leaves (Williams 1975). The spots enlarge, coalesce and develop to big necrotic spots, usually with a yellow halo, leading to premature leaf drop. The pathogen also invades the stem causing cracking with brown stripes. Pod infection appears as dark green water-soaked areas, from where the pathogen enters the seeds and causes discoloration and shriveling (Sikirou 1999). CoBB is seed-borne (Sikirou 1999) and the pathogen can be spread by wind-driven rain and insects (Zandjanakou-Tachin et al. 2007), but also crop debris and weeds can play a role as inoculum sources (Sikirou and Wydra 2004). Different strategies are used to control the disease including cultural practices (Emechebe and Florini 1997), intercropping (Sikirou 1999; Sikirou and Wydra 2008), application of chemicals (Rao and Hiremath 1985; Kotchoni et al. 2007), and sowing pathogenfree seeds (Emechebe and Shoyinka 1985; Soni and Thind 1991). Cultivation of resistant cowpea genotypes appears to be a promising strategy with potential to control CoBB (Emechebe and Shoyinka 1985; Khatri-Chhetri 1999; Sikirou 1999). In cowpea, reliable assays have been established for screening for resistance to bacterial blight. The assays are based on leaf spray-infiltration with bacterial suspensions on the abaxial surface without injuring the leaves and inoculation of the stem by inserting a sharp toothpick, contaminated with bacterial suspension (Sikirou 1999; Sikirou and Wydra 2004). High variability was found among Xanthomonas axonopodis pv. vignicola strains from Africa and from worldwide origin, and also sources of resistance among cowpea genotypes to CoBB showed wide variation in their reaction to Xav strains (Bua et al. 1998; Sikirou 1999; KhhatriChhetri 1999; Okechukwu and Ekpo 2004). However, little is known about inheritance of the resistance to this disease. Prakash and Shivashankar (1984) studied the inheritance to CoBB in the field by crossing the resistant parent '779' with four susceptible cultivars and reported that susceptibility was dominant over resistance and segregation patterns did not fit into simple genetic ratios. The resistance appeared to be inherited quantitatively and segregation was affected by the genetic background of parents and modifying factors.

Marker assisted selection (MAS) would help to develop high yielding cowpea varieties combining important agronomic traits with resistance to bacterial blight. Until recently only limited use was made of molecular marker techniques to enhance cowpea breeding. Restriction fragment length polymorphisms (RFLPs) have produced only a limited number of markers that could not facilitate QTL studies (Fatokun et al. 1992, 1993a, b; Menancio-Hautea et al. 1993; Myers et al. 1996; Menendez et al. 1997). Random amplified polymorphism DNA (RAPD) was used by several researchers (Menendez et al. 1997; Mignouna et al. 1998; Fall et al. 2003; Sylla Ba et al. 2004; Badiane et al. 2004; Diouf and Hilu 2005; Xavier et al. 2005). However, RAPDs are not very reproducible between laboratories, and therefore their use for breeding is limited. Simple sequences repeats (SSRs) markers are being used in cowpea breeding, but the number of markers is still limited ( $\mathrm{Li}$ et al. 2001; Wang et al. 2004; Diouf and Hilu 2005). Amplified fragments length polymorphisms (AFLPs) were found to be the most informative and were used successfully in many studies (Fatokun et al. 1997; Ouédraogo et al. 2001, 2002a, b; Coulibaly et al. 2002; Tosti and Negri 2002; Boukar et al. 2004; Omo-Ikerodah et al. 2008; Muchero et al. 2009a). 
Single nucleotides polymorphisms (SNPs) offer important advantages over the above-mentioned marker systems used for cowpea breeding so far. SNPs are the most abundant type of genetic polymorphism in most, if not all genomes (coding and non-coding regions) (Slate et al. 2009). SNPs have greater utility than the other marker types for their higher genotyping efficiency, data quality, genomewide coverage, analytical simplicity and cost effectiveness (Morin et al. 2004). The development of SNPs consensus genetic map of cowpea (Muchero et al. 2009b) opened up new possibilities for cowpea genomics and breeding, in particular for quantitative analysis such as bacterial blight resistance in cowpea.

In the present study we focused on foliar bacterial blight expression of cowpea. By making use of the SNP information for cowpea we wanted to (i) determine the genetics of resistance to CoBB, (ii) identify molecular markers with strong associations to foliar CoBB resistance and (iii) map chromosomal regions (QTLs) involved in the resistance. We used a SNP based genetic linkage map derived from a set of recombinant inbred lines (RILs) which resulted from a cross between Danila (resistant parent) and TVu7778 (susceptible parent). We report here identification of regions of the genome with QTLs for resistance to CoBB and discuss the utility of the SNP loci linked to the disease resistance phenotypes in MAS of CoBB resistance.

\section{Materials and methods}

Sites and greenhouse conditions

Experiments were conducted in the pathology laboratory and greenhouses of the International Institute of Tropical Agriculture (IITA) in Ibadan $\left(7^{\circ} 30^{\prime} \mathrm{N}\right.$, $3^{\circ} 54^{\prime} \mathrm{E}$ and $243 \mathrm{~m}$ altitude) located in the forestsavanna transition zone of South-West Nigeria. The mean temperatures and relative humidity were respectively $29.9^{\circ} \mathrm{C}$ and $80 \%$ in October 2007 , $32.6^{\circ} \mathrm{C}$ and $72 \%$ in March 2008.

\section{Inoculum preparation}

Highly virulent Xanthomonas axonopodis pv. vignicola strains Xav18 and Xav19 isolated from Kano (Sikirou 1999) were grown on nutrient agar (NA) medium for $48 \mathrm{~h}$ at $28^{\circ} \mathrm{C}$. After harvesting bacterial colonies with sterile distilled water, the concentration was adjusted to an optical density $(\mathrm{OD})=0.06$ corresponding to $10^{8}$ colony forming units $/ \mathrm{ml}$ (CFU/ml) with a spectrophotometer. A few drops of Tween 20 were added both to the bacterial suspension and to the sterile distilled water to be used for control plants just before inoculation.

Plant materials and inoculation

Cowpea genotypes IT81D-1228-14 (reported to be resistant to CoBB; Singh et al. 1997; Amusa and Okechukwu 1998; Okechukwu and Ekpo 2004), IT90K-76 and IT84S-2246-4 (known to be susceptible to CoBB; Sikirou 1999; Okechukwu and Ekpo 2004) were used to determine bacterial concentration and the optimal growth stage most effective for inoculations under the greenhouse conditions in Ibadan IITA station. Two inoculation methods were employed, one on the leaf and the second on the stem. A total of eleven genotypes (see Table 1) including three parental lines of existing RIL populations (Danila, TVu11986 and TVu7778) were screened using the two highly virulent strains of Xanthomonas axonopodis pv. vignicola (Xav) isolated from Kano by Sikirou (1999). Plastic pots ( $8 \mathrm{~cm}$ diameter) were filled with sterilized topsoil and genotypes were planted in four sets of which each set consisted of 22 pots with two pots per genotypes. Four seeds were sown per pot and were watered with tap water. The seedlings were thinned to two plants per pot. Three weeks after planting, three sets of 22 pots each were arranged in randomized block design with three replications. Plants were inoculated with bacterial suspension at a concentration of $2 \times 10^{6}(\mathrm{CFU} / \mathrm{ml})$. Twenty-four hours before inoculation, plants were placed under high humidity conditions to allow stomata opening. Plants were covered with plastic bags and kept under humidity for $48 \mathrm{~h}$ after inoculation to enhance the establishment of infection. The inoculation was done by spraying the abaxial surface of the first two trifoliates until water-soaked spots appeared using a hand-operated atomizer as described (Sikirou 1999; Okechukwu and Ekpo 2004). In the fourth set, two plants per genotype were used for stem inoculation by inserting a sharp tooth-pick, contaminated with $48 \mathrm{~h}$ old bacterial suspension and two plants per 
genotype were inoculated with sterile distilled water as control.

After the initial analysis was carried out to determine which genotypes were susceptible or resistant to $\mathrm{CoBB}$, a set of recombinant inbred lines (RILs) comprising 113 individuals derived from the cross between Danila (CoBB resistant line) and TVu7778 (CoBB susceptible line) was evaluated for reaction to cowpea bacterial blight infection using the most virulent strain (Xav18). This experiment used a completely randomized design with two replications. Four plants per line and two trifoliates per plant were inoculated with bacterial suspension as described above. The experiments were repeated twice under controlled conditions (October 2007 and March 2008).

Evaluation of disease reactions

Disease severity was visually scored for 27 days after inoculation (dai) on the infested leaves using a severity scale of 0 (no symptom), 1 (leaf spots symptoms, i.e. translucent and water-soacked spots), 2 (leaf blight: 10-50\% leaf area infected), 3 (severe blight symptoms: $>50 \%$ leaf area infected), 4 (inoculated trifoliate is shed). Seven evaluations were performed, 5, 7, 9, 12, 16, 21 and 27 dai. Foliar disease severity data of genotypes and RILs were subjected to analysis of variance and Duncan Multiple Rank Test (test level $5 \%$ ) was used to determine significant differences between genotypes. The area under disease progress curve (AUDPC) was calculated for each RIL from the disease reaction scores $5,7,9,12,16,21$ and 27 dai by using the formula $A U D P C=\sum_{i}\left[\left(D_{i}+D_{i-1}\right) \times\right.$ $\left.\left(t_{i}-t_{i-1}\right)\right] / 2$, where $D_{i}=$ disease score at time $t_{i}$ using the 0 to 4 scores and $t_{i}=$ time measured in days after inoculation (Shaner and Finney 1977).

\section{Genotyping and genetic map construction}

Growth of plants and DNA isolation were conducted at the University of California, Riverside (UCR). Parental genotypes and RILs from the DanIla $\times \mathrm{TVu} 7778$ mapping population were genotyped with 1536 SNPs using the Illumina GoldenGate assay as described in Muchero et al. (2009b). A set of 282 segregating SNP markers with minor allele frequency MAF $>0.3$ was used to construct the genetic linkage map. JoinMap 4.0 (Van Ooijen 2006) was used to construct the map. The Kosambi

Table 1 Disease severity and reaction of foliar symptoms to CoBB strains (Xav18 Xav19) in eleven cowpea genotypes

\begin{tabular}{|c|c|c|c|c|c|c|c|c|}
\hline \multirow[t]{3}{*}{ Genotype } & \multicolumn{4}{|c|}{ Experiment 1 (March 2007) } & \multicolumn{4}{|c|}{ Experiment 2 (Aug. 2007) } \\
\hline & \multicolumn{2}{|l|}{ Xav18 } & \multicolumn{2}{|l|}{ Xav19 } & \multicolumn{2}{|l|}{ Xav18 } & \multicolumn{2}{|l|}{ Xav19 } \\
\hline & $S$ & DR & $\mathrm{S}$ & DR & $\mathrm{S}$ & DR & $S$ & DR \\
\hline IT81D-1228-14(1) ${ }^{\mathrm{a}}$ & $0.25 \mathrm{a}$ & $\mathrm{R}$ & $0.20 \mathrm{a}$ & $\mathrm{R}$ & $0.5 \mathrm{a}$ & $\mathrm{R}$ & $0.42 \mathrm{a}$ & $\mathrm{R}$ \\
\hline Aloka & $0.33 \mathrm{a}$ & $\mathrm{R}$ & $0.33 \mathrm{a}$ & $\mathrm{R}$ & $0.75 \mathrm{a}$ & $\mathrm{R}$ & $0.75 \mathrm{a}$ & $\mathrm{R}$ \\
\hline Danila & $0.5 \mathrm{a}$ & $\mathrm{R}$ & $0.42 \mathrm{a}$ & $\mathrm{R}$ & $1 \mathrm{a}$ & $\mathrm{R}$ & $1 \mathrm{a}$ & $\mathrm{R}$ \\
\hline TVu11986 & $3 b$ & $\mathrm{~S}$ & $2.5 \mathrm{~b}$ & MS & $3 b$ & $\mathrm{~S}$ & $2.75 b$ & MS \\
\hline IT81D-994 & $3 b$ & $\mathrm{~S}$ & $2.75 b$ & MS & $3 b$ & $\mathrm{~S}$ & $2.75 b$ & MS \\
\hline IT98K-205-8 & $3 b$ & $\mathrm{~S}$ & $2.75 b$ & MS & $3 b$ & $\mathrm{~S}$ & $2.85 \mathrm{c}$ & MS \\
\hline IT90K-76 & $3.25 b c$ & $\mathrm{~S}$ & $3 b c$ & $\mathrm{~S}$ & $3.5 b$ & $\mathrm{~S}$ & $3.5 \mathrm{c}$ & $\mathrm{S}$ \\
\hline IT98K-216-44 & $3.5 \mathrm{~cd}$ & $\mathrm{~S}$ & $3.5 \mathrm{~cd}$ & $\mathrm{~S}$ & $3.8 \mathrm{~cd}$ & $\mathrm{~S}$ & $3.75 \mathrm{c}$ & $\mathrm{S}$ \\
\hline TVu4676 & $3.75 \mathrm{de}$ & $\mathrm{S}$ & $3.75 d$ & $\mathrm{~S}$ & $4 d$ & $\mathrm{~S}$ & $4 d$ & S \\
\hline TVu7778 & $3.83 \mathrm{de}$ & $\mathrm{S}$ & $3.75 \mathrm{~d}$ & $\mathrm{~S}$ & $4 d$ & $\mathrm{~S}$ & $4 d$ & $\mathrm{~S}$ \\
\hline IT84S-2246-4 & $4 \mathrm{e}$ & $\mathrm{S}$ & $3.85 \mathrm{~d}$ & $\mathrm{~S}$ & $4 d$ & $\mathrm{~S}$ & $4 d$ & $\mathrm{~S}$ \\
\hline
\end{tabular}

${ }^{a}$ IT81D-1228-14 (1) is the most resistant genotype selected from the original IT81D-1228-14 received from IITA genebank over 3 generations based on single plant selection with best resistance to both Xav18 and Xav19

Mean values in the same column followed by the same letter(s) are not significant different $(P \leq 0.05)$ using Duncan Multiple Rank Test. S: severity, DR: disease reaction; R: resistant (severity score $\leq 1)$, MS: moderately susceptible $(1<$ severity score $<3$ ); S: susceptible (severity $\geq 3$ ) 
mapping function (Kosambi 1944) was used to convert recombination frequencies to centiMorgans. To assign markers to linkage groups, a step-wise reduction of LOD score above 3 with maximum recombination of 0.45 was used.

\section{QTL mapping}

The SNP genetic linkage map was used to identify markers associated with QTLs that have effects on resistance to cowpea bacterial blight using the computer program MapQTL 5.0 (Van Ooijen 2004). Entry means for disease scores for each of the 7 evaluation days separately and overall means of all evaluations days and AUDPC means for each experiment were used for QTL analyses. The analysis started first with a non-parametric Kruskall-Wallis test to identify markers that showed significant (stringent $>0.005$ ) association with phenotypic traits. The next step was Interval Mapping (IM) to identify putative QTLs. Markers located in the vicinity of the QTL were selected as initial set of cofactors. The Multiple-QTL model Mapping (MQM) method was used to more precisely locate QTL using automatic cofactor selection. A permutation test was applied to each data set (1000 permutations) to determine the LOD (Logarithm of odds) thresholds. A genome wide (GW) LOD threshold of 2 was used for QTL significance at $95 \%$ confident interval. The chromosomal location with the highest GW LOD score was considered to be the most likely position of a QTL. Graphics were produced by MapChart software (Voorrips 2002).

\section{Results}

Screening cowpea genotypes for novel sources of resistance to $\mathrm{CoBB}$

Cowpea bacterial blight (CoBB) symptoms start with small water soaked spots on leaves which enlarge to irregular brown necrotic lesions surrounded by yellow haloes. The pathogen also invades cowpea stem causing canker symptoms on susceptible plants. Therefore a cowpea cultivar with resistance to both foliar and stem disease expressions is desirable. In this study, we inoculated leaf and stem of eleven selected cultivars with the pathogen, but no stem canker symptoms were observed in all the genotypes tested. Two types of foliar symptoms were observed on the cowpea plants: blight translucent spots that enlarge leading to premature leaf drop on the susceptible genotypes and brown leaf spots with limited lesion areas on the resistant genotypes. The eleven cowpea genotypes screened in this study differed significantly $(P<0.01)$ in severity of their foliar disease symptoms following inoculation with both Xav18 and Xav19 strains. The overall mean of visual scores for disease severity and disease reactions are shown in Table 1. After the first appearance of leaf translucent spots, lesion areas of the inoculated leaves continued to increase with yellow surroundings in the susceptible genotypes (IT84S2246-4, TVu7778, IT90K-76, IT98K-205-8, IT98K216-44, TVu14676). In both experiments, only the known susceptible control IT84S-2246-4 showed systemic expression of leaf spots on non-infested leaves when inoculated with Xav18 and the infected leaves dropped early. When inoculated with Xav19 the cowpea genotypes TVu11986, IT81D-994 and IT98K-205-8 were classified as moderately susceptible (MS) with disease severity ranging between 2.5 and 3 while the same genotypes were classified as susceptible with severity greater than 3 when inoculated with Xav18. In the MS genotypes blight spots enlarged up to $75 \%$ of leaf area infected but no leaves were shed. The resistant genotypes Danila and Aloka locally developed brown leaf spots with limited lesion area and severity score ranged between 0.33 and 1. Genotype IT81D-1228-14 (1) showed disease scores $\leq 0.5$ for both Xav18 and Xav19. IT81D-122814 (1) and was the most resistant genotype, followed by Aloka local and Danila. The CoBB strain Xav18 was more aggressive with a shorter latency period compared to Xav19. The availability of a set of RILs developed from a cross of Danila and another cowpea line TVu7778 enabled us to study the genetics of the resistance.

\section{CoBB resistance segregation}

Disease severity was assessed by visual inspection of lesion areas on infected leaves and scored in five classes (0-4). The area under disease progress curve (AUDPC) was calculated using severity score data according to the formula explained in the methods section. The correlations between the disease rating 
and AUDPC were 0.96 and 0.94 for the first (2007) and second (2008) experiments respectively indicating good agreement between the two methods. Disease scores were used to study segregation patterns in the set of RILs from the cross between Danila and TVu7778. Considerable differences were observed among of the individual RILs for the first appearance of leaf spots on the abaxial surface and days to first leaf drop. The latency period was longer during the second experiment where disease assessment started seven dai compared to five dai in the first experiment when the first leaf spot symptoms appeared on the most susceptible lines including TVu7778. Based on mean square $\left(\mathrm{MS}_{\mathrm{g}}\right)$ considered as total phenotypic variation and experimental errors (MSe) as an estimate of non-genetic variation of ANOVA, the estimated heritability for disease reactions to CoBB were 0.93 and 0.92 in the first and second experiments respectively. Disease symptoms in both experiments were highly correlated (0.87). The frequency distribution of the RIL population based on foliar disease severity scores showed a bimodal pattern in both experiments (Fig. 1) with some transgressive lines towards resistance and susceptibility. Each line was classified based on disease rating of 0 (no symptom) to 1 (symptom with limited lesion area $\leq 10 \%)$ as resistant $(\mathrm{R})$, a line with disease rating between 2 and $3(10 \%<$ lesion area $<75 \%$ ) as moderately susceptible (MS) and disease rating greater than 3 (lesion area $>75 \%$ ) to 4 (leaf drop) as susceptible (S). Based on this classification, in both experiments there were a larger number of lines with intermediate and susceptible reactions than resistant lines, and the distribution of intermediates was skewed toward susceptibility (Fig. 2).

\section{Genetic map and QTL mapping}

The genetic linkage map of cowpea constructed from the set of 113 RILs developed from cross between Danila and TVu7778 consisted of 282 SNP markers. The markers were selected from the 1536 SNP genotyping array used for the consensus map of cowpea (Muchero et al. 2009b). Only markers with minor allele frequencies $>0.3$ were used. The map consisted of 11 linkage groups (LGs) and a total size of $633 \mathrm{cM}$. The sizes of LGs and the number of markers assigned to the different LG varied between
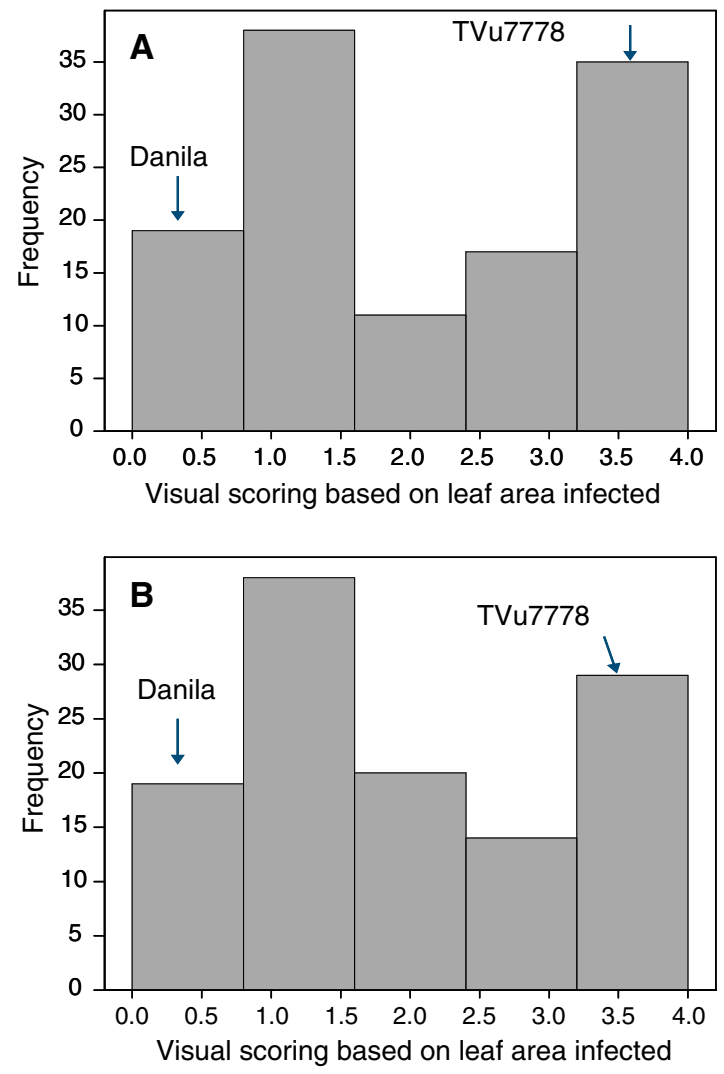

Fig. 1 Frequency distribution of foliar disease severity of bacterial blight Xav18 strain in cowpea RILs derived from cross between Danila and TVu7778. a First experiment (October 2007), (b): second experiment (March 2008). Arrows indicate the disease scoring values for Danila (tolerant parent) and TVu7778 (susceptible parent)

$31.6 \mathrm{cM}$ for LG1 (21 loci) and $111.62 \mathrm{cM}$ for LG3 (58 loci). This genetic map was used to perform QTL analysis using as traits entry means of disease rating for each evaluation day separately and overall means disease rating and AUDPC values per experiment. Results of a (non-parametric) Kruskall-Wallis Test revealed 11 SNP loci significantly associated (at a significance $0.01<P<0.0001$ ) with phenotypic data expressed as AUDPC and disease rating. These marker loci associated with phenotypic data were of minor allele frequency (MAF) ranging from 0.381 to 0.496 indicating a normal (1:1) segregation pattern. The 11 SNP loci defined three QTLs on LG3, LG5 and LG9 as assessed with interval mapping, and confirmed with Multiple QTL mapping. Biometrical characteristics of QTLs are presented in Table 2. All three QTLs named CoBB-1, CoBB-2 and CoBB-3 
Fig. 2 Localisation of QTLs for CoBB resistance to single virulent strain of Xanthomonas axonopodis pv. vignicola on RILs population derived from Danila and TVu7778 on LG3, LG5 and LG9. QTLs [CoBB-1(Exp1), CoBB2(Exp1), CoBB-3(Exp1)] and [CoBB-1(Exp2), CoBB-2(Exp2)] represent QTLs identified at LOD $>2$ for first (carried out October 2007) and second (carried out March 2008) experiments respectively

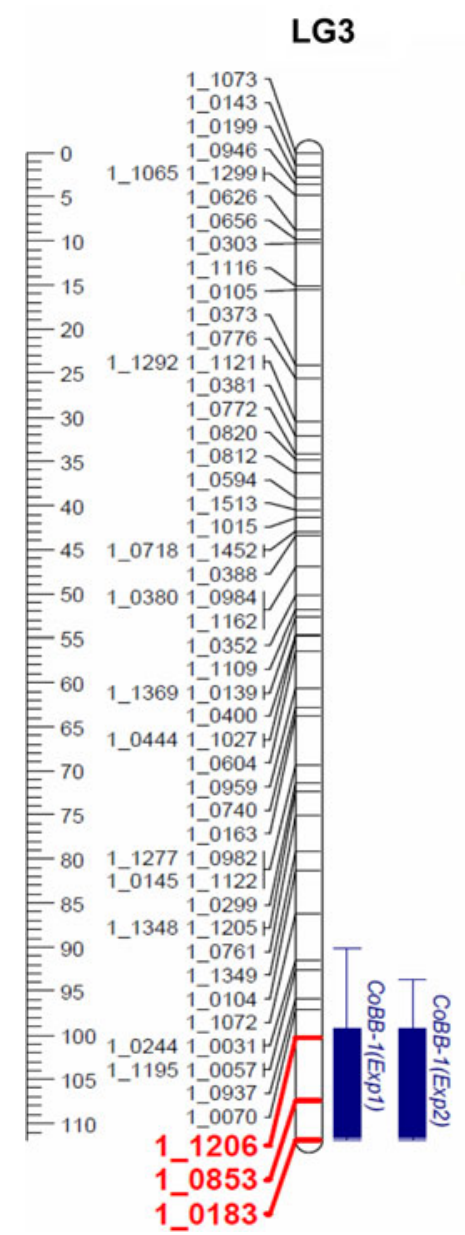

LG5

LG9
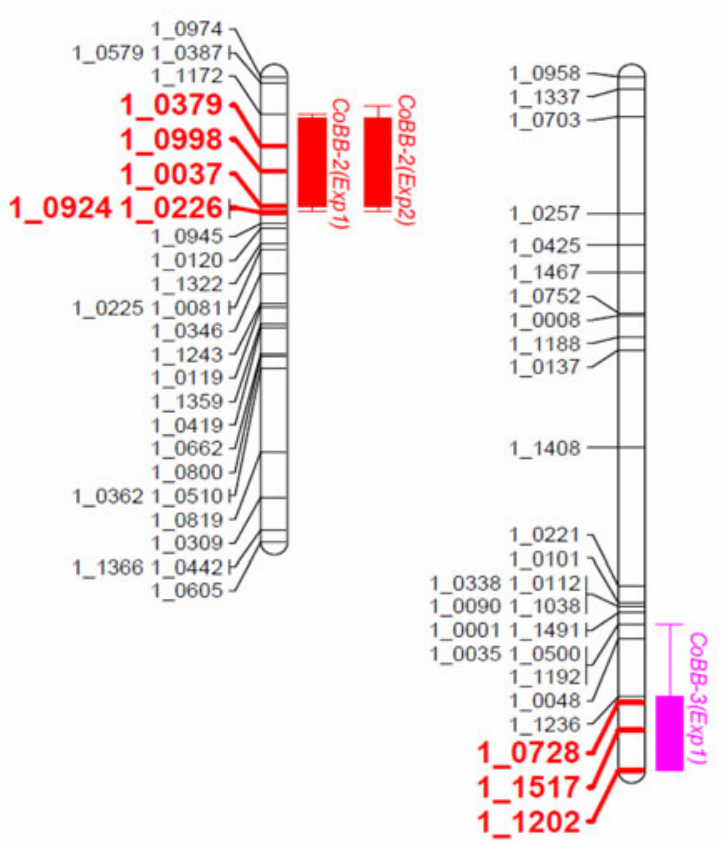

were detected in the first experiment. In the second experiment the QTLs CoBB-1 and CoBB-2 on LG3 and LG5 respectively were found as well. The two QTLs CoBB-1 and CoBB-2 were consistently discovered using the data sets of the last three evaluations days (16, 21 and 27 dai), and were found using overall means of disease rating well as and AUDPC disease scoring data. The QTL CoBB-3 on LG9 was discovered only with disease ratings $(16,21$ and 27 dai) of the first experiment. No QTL was found for disease rating and AUDPC five and seven dai in either experiment. The two chromosomal regions on LG 3 (99.9-111.6 cM) and LG5 (4.3-16.8 cM) where QTLs CoBB-1 and CoBB-2 were consistently identified for the first and second experiment represent two major regions for CoBB resistance. The QTL on LG3 explained up to $22.1 \%$ and up to $17.4 \%$ of the phenotypic variance associated with response of Xav18 in the first and second experiments respectively. The most significant QTL (CoBB-2) was located in LG5 with marker 1_0037 showing the highest LOD (3.36) and variation explained (22.1\%). The QTL CoBB-3 detected only in the first experiment showed the lowest phenotypic variation explaining of about $10 \%$ of the variance.

\section{Discussion}

Bacterial blight caused by Xanthomonas axonopodis pv. vignicola $(X a v)$ is one of the major diseases of cowpea giving rise to yield loss in all cowpea growing areas. The disease could be particularly devastating in drought prone areas of sub-Saharan Africa. The development of cowpea lines with resistance to this disease would be most attractive to farmers as a means of ameliorating the adverse effects of the disease in cowpea fields. Cultural 
Table 2 Biometrical parameters of QTLs identified showing linkage groups, position of QTLs, LOD scores, phenotypic variation explained and the most significant SNP loci associated with disease resistance phenotypes

\begin{tabular}{llclllll}
\hline QTL & LG & Position(cM) & Marker & K-W & Relevant & MQM \\
\cline { 5 - 7 } & & & & Significant & Data set & LOD & \% Explained \\
\hline CoBB-1 & 3 & $95.7-111.6$ & 1_0853 & 0.001 & Exp1 & 2.98 & $5.6-15.8$ \\
CoBB-1 & 3 & $99.9-111.6$ & $1 \_0183$ & 0.001 & Exp2 & 2.69 & $4.7-13.9$ \\
CoBB-2 & 5 & $4.3-16.8$ & $1 \_0037$ & 0.0001 & Exp1 & 3.36 & $9.2-22.1$ \\
CoBB-2 & 5 & $4.3-18.6$ & 1_0037 & 0.0001 & Exp2 & 3.10 & $6.7-17.4$ \\
CoBB-3 & 9 & $71.2-78.6$ & 1_1202 & 0.001 & Exp1 & 2.28 & $4.3-9.72$ \\
\hline
\end{tabular}

SNP markers are those of higest LOD scores and variation explained within the respective QTL regions, relevant data set indicates the experiment for which QTL parameters are shown, 0.001, 0.0001 significant level as revealed by Kruskall-Wallis Test. QTLs on LG3 and LG5 were discovered in identical chromosome regions for the first experiment (Exp1) and second experiment (Exp2) and were therefore named CoBB-1 and CoBB-2. K-W: Kruskal-Wallis test

methods such as intercropping cowpea with maize or cassava could also help to minimize yield losses due to the disease (Sikirou and Wydra 2008). Previous research efforts on quick detection, identification and characterization of $X a \mathrm{v}$ have been carried out (Verdier et al. 1998; Sikirou 1999), but genetic inheritance of CoBB is still poorly understood. Two strains of CoBB (Xav18 and Xav19) from Kano identified as most virulent (Sikirou 1999) were used for single strain artificial inoculation under greenhouse conditions and new sources of resistance to the disease have been found including the cultivar Danila. As Danila and TVu7778 have shown contrasting response to CoBB symptoms on leaves, QTL analysis was performed using RILs population from the two genotypes and markers associated with QTLs that have effects on resistance to CoBB have been identified. These markers can also be placed on the integrated cowpea genetic linkage map (Muchero et al. 2009b).

Bacterial blight symptoms were observed on leaves inoculated with $2 \times 10^{6} \mathrm{CFU} / \mathrm{ml}$ bacterial suspensions. However, symptoms were observed on non-infested leaves of the susceptible line IT84S2246-4 confirming the systemic nature of the disease. Stem inoculation by inserting a sharp tooth-pick contaminated with bacterial suspension as suggested by Sikirou (1999) and Sikirou and Wydra (2004) using two CoBB strains did not induce canker symptoms on stems in both susceptible and resistant cowpea lines tested. It appears that most of the genotypes investigated here were indeed resistant to stem canker expression. The absence of stem canker expression even in genotypes that showed high expression of leaf symptoms may indicate that different genes could be responsible for CoBB expression in leaf and stem. In an earlier study Nebane (1980) found cowpea varieties with leaves that were resistant to blight development while the stems showed canker expression. The author suggested that phytoalexins which confer resistance to the disease may be produced more in the leaves than in the stems of such varieties. Okechukwu and Ekpo (2004) reported that stem canker expression on cowpea is dependent on genotype. However, it can not be ruled out that stem inoculation was not successful in the experiments reported here; further studies are needed to ascertain this observation.

With a RIL population, a 1:1 ratio for resistant and susceptible genotypes is expected in case of Mendelian single gene segregation. However, this was not the case with the RILs used in this study in which plants were inoculated with $\operatorname{Xav}(18)$. The frequency distribution of disease rating displayed a bimodal pattern in both experiments with intermediate classes indicating that at least 2 complementary genes confer resistance to $\mathrm{CoBB}$ in this population, with putative modifying factors. For the resistance to CoBB in this population we identified two QTLs named CoBB-1 and CoBB-2 located on LG3 and LG5 which were consistent over the two experiments both for disease rating and AUDPC. Possibly a few minor QTLs, one of which may be CoBB-3 detected on LG9 in the first experiment, may represent modifying factors influencing disease resistance, which may explain the partial resistance of some of the RILs. These results agreed with those of Prakash and Shivashankar (1984) who reported quantitative inheritance of 
resistance to bacterial blight in cowpea with segregation affected by the genetic background of parents with modifying factors.

Based on the results obtained with our greenhouse inoculation and disease scoring procedure we were able to identify molecular markers that define QTL regions with effects on resistance to the disease. The three QTLs CoBB-1, CoBB-2 and CoBB-3 on linkage groups LG3, LG5 and LG9, respectively, represent resistance gene candidates (RGC) loci. In cowpea, Kelly et al. (2003) reported on RGCs using RFLP markers in these genes that were also placed in various locations on the integrated cowpea map including LG3, LG5, and LG9. This is a further indication that these LGs contain disease resistance genes in cowpea. Nevertheless, none of their RGC loci co-segregated with disease resistance. This could be due to the fact different genotypes were used in both studies. The quantitative nature of the resistance with two consistent QTLs conferring resistance to CoBB detected under controlled conditions is similar to the results of Jorge et al. (2001) who found two consistent QTLs for cassava bacterial blight when screening was performed under greenhouse conditions.

We found high heritability for the disease reaction to $\left(\right.$ Xav18) in this population, $\mathrm{h}^{2}=0.93$ and 0.92 for the first and second experiment respectively. However, this estimate obtained under greenhouse conditions might not reflect the reality observed under field conditions. Sikirou (1999), Okechukwu and Ekpo (2004) indicated that the resistance to CoBB is severely influenced by environmental factors. Okechukwu and Ekpo (2004) and Ajeigbe et al. (2008) reported that Danila was susceptible under field conditions in Kano. This is not surprising since at Minjibir farms (Kano) where they carried out experiments, a mixture of pathotypes and heavy load of CoBB inoculum might be present in the field as result of continuous cowpea plantation, while in our study Danila was found resistant using a single strain (Xav18, Xav19) of CoBB under greenhouse conditions. Similarly Miklas et al. (1996) demonstrated that in common bean different QTLs for resistance to bacterial blight were identified under greenhouse and field conditions. Moreover, varietal resistance to CoBB has been reported (Sikirou 1999) suggesting the existence of pathogenic variation in isolates of Xav. Selection of cowpea varieties with more widespread resistance after inoculation with different pathotypes is recommended to breeders (Wydra and Singh 1998). Additional screening in greenhouses and in the field with different pathotypes like those characterized by Verdier et al. (1998) is needed to detect other QTLs and molecular markers associated to CoBB resistance in order to breed for broad CoBB resistance. To confirm QTLs across populations, cowpea genotype IT81D1228-14(1) identified as most resistant to CoBB among the genotypes studied herein (Table 1) was crossed reciprocally with the most susceptible genotypes IT84S-2246-4 and IT90K-76. These populations represent potential mapping populations for confirmation of QTLs associated to CoBB resistance. The highthroughput SNP marker system as utilized in this study offers a good opportunity to identify candidate markers useful for pyramiding different CoBB resistance QTLs into cowpea varieties, and to produce elite cowpea varieties with broad resistance to bacterial blight by marker assisted selection.

Our results showed that only limited lesion areas were developed on resistant lines while lesion areas enlarged leading to leaf drop in the most susceptible lines. This finding agrees with what is known about cowpea's defense response mechanism to Xav, represented by a brown-red discoloration without complete collapse of the tissue (Gitaitis 1983). Plants employ a variety of defense mechanisms in response to pathogens, including the use of mechanical barriers, defense proteins and defensive enzymes (Pereira et al. 2003). A role for proteins in cell wall structure in bacterial blight disease resistance has been reported by different researchers in several plant species. In tomato, Wydra and Beri $(2006,2007)$ suggested that the structure of pectin cell wall polysaccharides and specifically the degree of their esterification might play a role in defense against a bacterial pathogen. Plant peroxidases can be directly involved in defense mechanisms acting as catalysts for the polymerization of phenolic compounds to form lignin and suberin in the cell wall, which can act as barriers to block the spread of the pathogen in the plant (Fritig et al. 1987). Flood et al. (1995) also suggested that peroxidases might play an important role in resistance to bacterial blight of cassava. A cationic peroxidase gene, MEPX1, was isolated from cassava and the DNA sequence of MEPX1 showed high homology with other plant peroxidase genes and contained a large intron typical of peroxidase genes (Pereira et al. 2003). The amino acid sequence had $75 \%$ homology with two 
Arabidopsis thaliana peroxidases. In cowpea, Kotchoni et al. (2007) detected a significant increase in $\mathrm{H}_{2} \mathrm{O}_{2}$-producing peroxidase (NADH-peroxidase) activity when cowpea plants were treated with $\mathrm{H}_{2} \mathrm{O}_{2}$ at seedling and vegetative growth stages. Although the mechanism of resistance is not elucidated for cowpea, the authors argued that treatment with $\mathrm{H}_{2} \mathrm{O}_{2}$ induces the synthesis of pathogenesis-related proteins, which help the plants to resist the pathogen attack. In cassava, Kpemoua et al. (1996) found that the production of phenolic compounds in the phloem and xylem of bacterial blight resistant cassava cultivars was significantly higher than in susceptible ones. There was also a higher accumulation of lignin and a greater formation of callose and tyloses in resistant cultivars which potentially obstruct the passage of the bacteria from cell to cell (Kpemoua et al. 1996). Also in cell walls of tomato genotypes resistant to Ralstonia solanacearum, the cell wall structure was altered compared to susceptible genotypes, with differences in the distribution of acetyl esters of petic polysaccharides (Wydra and Beri 2006; 2007). In this study, three of the SNP markers linked to CoBB resistance were homologous to extracellular dermal glycoprotein (1_0946), pectinacetylesterase family protein (1_0604) and ribosomal protein fibronectin (1_0225) (HarvEST:Cowpea [http://harvest.ucr.edu]). The localization of these potential proteins in the cell wall tissues may suggest that these proteins could have disease defense functions. Further investigations on these SNP loci might help in developing simple PCR markers to be used for marker assisted selection (MAS).

Acknowledgments We kindly acknowledged the help of Dr. Fen Beed and Dr. Rachidatou Sikirou from IITA Cotonou station for providing the Xanthomonas axonopodis pv. vignicola strains (Xav18, Xav19). Thanks to the technicians in the lab and to $\mathrm{Mr}$ Greg Ogbe. for helping in inoculation experiments.

Open Access This article is distributed under the terms of the Creative Commons Attribution Noncommercial License which permits any noncommercial use, distribution, and reproduction in any medium, provided the original author(s) and source are credited.

\section{References}

Ajeigbe HA, Singh BB, Emechebe AM (2008) Field evaluation of improved cowpea lines for resistance to bacterial blight, virus and striga under natural infestation in the West African Savannas. Afr J Biotechnol 7:3563-3568
Amusa NA, Okechukwu RU (1998) Reaction of selected cowpea (Vigna unguiculata L. Walp) breeding lines to Xanthomonas campestris pv. vignicola. Trop Agric Res Ext 1:162-164

Badiane FA, Diouf D, Sane D, Diouf O, Goudiaby V, Diallo N (2004) Screening cowpea [Vigna unguiculata (L.) Walp.] varieties by inducing water deficit and RAPD analyses. Afr J Biotechnol 3:174-178

Boukar O, Kong L, Singh BB, Murdock L, Ohm HW (2004) AFLP and AFLP-derived SCAR markers associated with Striga gesnerioides resistance in cowpea. Crop Sci 44:1259-1264

Bua B, Adipala E, Opio F (1998) Screening cowpea germplasm for resistance to bacterial blight in Uganda. Int $\mathrm{J}$ Pest Manag 44:185-189

Burkholder WH (1944) Xanthomonas vignicola sp. Nov. pathogenic on cowpea and bean. Phytopathology 34:430432

Coulibaly S, Pasquet RS, Papa R, Gepts P (2002) AFLP analysis of the phonetic organization and genetic diversity of Vigna unguiculata L. Walp. Reveals extensive gene flow between wild and domesticated types. Theor Appl Genet 104:358-366

Diouf D, Hilu KW (2005) Microsatellites and RAPD markers to study genetic relationships among cowpea breeding lines and local varieties in Senegal. Genet Resour Crop Evol 52:1057-1067

Emechebe AM, Florini DA (1997) Shoot and Pod diseases of cowpea induced by fungi and bacteria. In: Singh BB, Mohan Raj DR, Dashiell KE, Jackia EN (eds) Advances in cowpea research. Copublication of International Institute of Tropical Agriculture (IITA) and Japan International Reseach Center for Agricultural Sciences (JIRCAS), IITA, Ibadan, Nigeria, pp 176-192

Emechebe AM, Shoyinka SA (1985) Fungal and bacterial diseases of cowpeas in Africa. In: Cowpea research, production and utilization. Singh SR, Rachie KO (eds) Wiley, Chichester, UK, pp 173-192

Fall L, Diouf D, Fall-Ndiaye MA, Badiane FA, Gueye M (2003) Genetic diversity in cowpea [Vigna unguiculata (L.) Walp.] varieties determined by ARA and RAPD techniques. Afr J Biotech 2:48-50

Fatokun CA, Menancio-Hautea DI, Danesh D, Young ND (1992) Evidence for orthologous seed weight genes in cowpea and mungbean based on RFLP mapping. Genetics 132:841-846

Fatokun CA, Danesh D, Menancio-Hautea D, Young ND (1993a) A linkage map for cowpea (Vigna unguiculata [L.] Walp.) based on DNA markers. In: O'Brien SJ (ed) Genetic maps, 6th edn. Cold Spring Harbor Laboratory Press, Cold Spring Harbor, NY, pp 6257-6258

Fatokun CA, Danesh D, Young ND, Steqart EL (1993b) Molecular taxonomic relationship in the genus Vigna based on RFLP analysis. Theor Appl Genet 86:97-104

Fatokun CA, Young ND, Myers GO (1997) Molecular markers and genome mapping in cowpea. In: Singh B, Mohan Mohan Raj D, Dashiell K, Jackai L (eds) Advances in cowpea research. IITA and JIRCAS, Ibadan, pp 352-360

Flood J, Cooper RM, Deshappriya N, Day RC (1995) Resistance of cassava (Manihot esculenta) to Xanthomonas blight in vitro and in planta. Asp Appl Biol 42:277-284 
Fritig B, Kauffmann S, Dumas B, Geoffroy P, Kopp M, Legrand M (1987) Mechanism of the hypersensitivity response of plants. In: Evered D, Hermett S (eds) Plant resistance to viruses. Wiley, UK, pp 92-108

Gitaitis RD (1983) Two resistant responses in cowpea induced by different strains of Xanthomonas campestris pv. vignicola. Plant Dis 67:1025-1028

Jorge V, Fregene Vélez CM, Duque MC, Tohme J, Verdier V (2001) QTL analysis of field resistance to Xanthomonas axonopodis pv. manihotis in cassava. Theor Appl Genet 101:564-571

Kelly JD, Gepts P, Miklas PN, Coyne DP (2003) Tagging and mapping of genes and QTL and molecular markersassisted selection for traits of economic importance in bean and cowpea. Field Crops Res 82:135-154

Khatri-Chhetri GB (1999) Detection and characterization of Xanthomonas campestris pv. vignicola strains, incitant of cowpea bacterial blight and pustule, and studies on genotype/strain-interactions. PhD Thesis. Dept. of Plant Pathology and Plant Protection, Georg-August-University, Goettingen, Germany (submitted)

Kosambi DD (1944) The estimation of map distance from recombination values. Ann Eugen 12:172-175

Kotchoni OS, Torimiro N, Gachomo EW (2007) Control of Xanthomonas campestris pv. vignicola in cowpea following seed and seedling treatment with hydrogen peroxide and N-heterocyclic pyridinium chlorochromate. J Plant Pathol 89:361-367

Kpemoua K, Boher B, Nicole M, Calatayud P, Geiger JP (1996) Cytochemistry of defence responses in cassava infected by Xanthomonas campestris pv. manihotis. Can J Microbiol 42:1131-1143

Li C, Fatokun CA, Ubi B, Singh BB, Scoles GJ (2001) Determining genetic similarities and relationships among cowpea breeding lines and cultivars by microsatellite markers. Crop Sci 41:189-197

Menancio-Hautea D, Fatokun CA, Kumar L, Danesh D, Young ND (1993) Comparative genome analysis of mungbean (Vigna radiata L. Wilczek) and cowpea (Vigna unguiculata L.) using RFLP mapping data. Theor Appl Genet 86:797-810

Menendez CM, Hall AE, Gepts P (1997) A genetic linkage map of cowpea (Vigna unguiculata) developed from a cross between two inbred, domesticated lines. Theor Appl Genet 95:1210-1217

Mignouna HD, Ng NQ, Ikea J, Thottapilly G (1998) Genetic diversity in cowpea as revealed by random amplified polymorphic DNA. J Genet Breed 52:151-159

Miklas PN, Johnson E, Stone V, Beaver JS, Montoya C, Zapata M (1996) Selective mapping of QTL conditioning disease resistance in common bean. Crop Sci 36:1344-1351

Morin PA, Luikart G, Wayne RK et al (2004) SNP in ecology, evolution and conservation. Trend Ecol Evol 19:208-216

Muchero M, Ehlers JD, Close TJ, Roberts PA (2009a) Mapping QTL for drought stress-induced premature senescence and maturity in cowpea [Vigna unguiculata (L.) Walp.]. Theor Appl Genet 118:849-863

Muchero M, Diop NN, Bhat PR, Fenton RD, Wanamaker S, Pottorff M, Hearne S, Cisse N, Fatokun C, Ehlers JD, Roberts PA, Close TJ (2009b) A consensus genetic map of cowpea [Vigna unguiculata (L.) Walp.] and synteny based on EST-derived SNPs. PNAS 106:18159-18164

Myers GO, Fatokun CA, Young ND (1996) RFLP mapping of and aphid resistance gene in cowpea (Vigna unguiculata L. Walp). Euphytica 91:181-187

Nebane CLN (1980) Inoculation techniques for studying the reaction of cowpea (Vigna unguiculata (L.) Walp) to infection by Xanthomonas vignicola Burkholder. MSc Thesis, University of Ibadan, Ibadan, p 52

Okechukwu RU, Ekpo EJA (2004) Sources of resistance to cowpea bacterial blight disease in Nigeria. J Phytopathol 152:345-351

Omo-Ikerodah EE, Fawole I, Fatokun CA (2008) Genetic mapping of quantitative trait loci (QTLs) with effects on resistance to flower bud thrips (Megalurothrips sjostedti) identified in recombinant inbred lines of cowpea (Vigna unguiculata (L.) Walp). Afr J Biotech 7:263-270

Ouédraogo JT, Maheshwari V, Berner DK, St-Pierre CA, Belzile F, Timko MP (2001) Identification of AFLP markers linked to resistance of cowpea (Vigna unguiculata L.) to parasitism by Striga gesnerioides. Theor Appl Genet 102:1029-1036

Ouédraogo JT, Gowda BS, Jean M, Close TJ, Ehlers JD, Hall AE, Gillespie AG, Roberts PA, Ismail AM, Bruening G, Gepts P, Timko MP, Belzile FJ (2002a) An improved genetic linkage map for cowpea (Vigna unguiculata L.) combining AFLP, RFLP, RAPD and Biochemical markers. Genome 45:175-188

Ouédraogo JT, Tignegre J, Timko MP, Belzile FJ (2002b) AFLP markers linked to resistance against Striga gesneriodes race 1 in cowpea (Vigna unguiculta). Genome 45:787-793

Pereira LF, Goodwin PH, Erickson L (2003) Cloning of a peroxidase gene from cassava with potential as a molecular marker for resistance to bacterial blight. Braz Arch Biol Technol 46:149-154

Prakash CS, Shivashankar G (1984) Inheritance of resistance to bacterial blight (Xanthomonas campestris pv. Vignicola) in cowpea. Genet Agrar 38:1-10

Rao KSP, Hiremath RV (1985) Influence of host nutrition on the severity of bacterial blight of cowpea. Indian Phytopathol 38:81-84

Shaner G, Finney RE (1977) The effect of nitrogen fertilization on the expression of slow-mildewing resistance in Knox wheat. Phytopathology 67:1051-1056

Sikirou R (1999) Epidemiological investigations and development of integrated control methods of bacterial blight of cowpea caused by Xanthomonas campestris pv. vignicola. $\mathrm{PhD}$ thesis. University of Göttingen, Germany, p. 218

Sikirou R, Wydra K (2004) Persistence of Xanthomonas axonopodis pv. vignicola in weeds and crop debris and identification of Sphenostylis stenocarpa as a potential new host. Eur J Plant Pathol 110:939-947

Sikirou R, Wydra K (2008) Effect of intercropping cowpea with maize or cassava on cowpea bacterial blight and yield. J Plant Dis Prot 115:145-151

Singh BB, Chambliss OL, Sharma B (1997) Recent advances in cowpea breeding. In: Singh BB, Mohan Raj DR, Dashiell KE, Jackai LEN (eds) Advances in cowpea research. IITA and Japan International Research Center 
for Agricultural Sciences (JIRCAS), Ibadan, Nigeria, pp 30-49

Slate J, Gratten J, Beraldi D, Stapley J, Hale M, Pemberton JM (2009) Gene mapping in the wild with SNPs: guidelines and future directions. Genetica 136:97-107

Soni PS, Thind BS (1991) Detection of Xanthomonas campestris pv. vignaeradiatae from green gram seeds and $\mathrm{X}$. campestris pv. vignicola (Burkh). Dye from cowpea seeds with the help of bacteriophages. Plant Dis Res 6:611

Sylla Ba F, Pasquet RS, Gepts P (2004) Genetic diversity in cowpea [Vigna unguiculata (L.)] as revealed by RAPD markers. Genet Resour Crop Evol 51:539-550

Tosti N, Negri V (2002) Efficiency of three PCR-based markers in assessing genetic variation among cowpea (Vigna unguiculata subsp. Unguiculata) landraces. Genome 45:268-275

Van Ooijen JW (2004) MapQTL 5: software for the mapping of quantitative trait loci in experimental population. Kyazma BV, Wageningen, The Netherlands

Van Ooijen JW (2006) JoinMap 4.0: software for the calculation of genetic linkage maps in experimental populations. Plant Research International, Wageningen

Vauterin L, Hoste B, Kersters K, Swings J (1995) Reclassification of Xanthomonas. Int J System Bacteriol 45: 472-489

Verdier V, Assigbetse K, Khatri-Chhetri G, Wydra K, Rudolph K, Geiger J (1998) Molecular characterization of the incitant of cowpea bacterial blight and pustule, Xanthomonas campestris pv. vignicola. Eur J Plant Pathol 104: 595-602
Voorrips RE (2002) MapChart: software for the graphical presentation of linkage maps and QTLs. J Hered 93:77-78

Wang ML, Gillaspie AG, Newman ML, Dean RE, Pittman RN, Morris JB, Pederson GA (2004) Transfer of simple sequence repeat (SSR) markers across the legume family for germplasm characterization and evaluation. Plant Genet Resour 2:107-119

Williams RJ (1975) Diseases of cowpea (Vigna unguiculata (L.) Walp.) in Nigeria. PANS 21:253-267

Wydra K, Beri H (2006) Structural changes of homogalacturonan, rhamnogalacturonan I and arabinogalactan protein in xylem cell walls of tomato genotypes in reaction to Ralstonia solanacearum. Physiol Mol Plant Pathol 68:41-50

Wydra K, Beri H (2007) Immunohistochemical changes in methyl-ester distribution of homogalacturonan and side chain composition of rhamnogalacturonan I as possible components of basal resistance in tomato inoculated with Ralstonia solanacearum. Physiol Mol Plant Pathol 70: 13-24

Wydra K, Singh BB (1998) Breeding for resistance to multiple strains of cowpea bacterial blight. IITA Annual Report 1998. Project 11, pp 25-27

Xavier GR, Vieira Martin LM, Raumjanek NG, Freire Filho RF (2005) Cowpea genetic variability analyzed by RAPD markers. Pesq Agropecu Bras Brasilia 40(4):353-359

Zandjanakou-Tachin M, Fanou A, LeGall P, Wydra K (2007) Detection, survival and transmission of Xanthomonas axonopodis pv. manihotis and $X$. axonopodis pv. vignicola, causal agents of cassava and cowpea bacterial blight, respectively, in/by insect vectors. J Phytopathol 155:159_ 169 